\title{
PERSEPSI MASYARAKAT KECAMATAN TOMPASO TERHADAP PEMAKAIAN GIGI TIRUAN
}

\author{
${ }^{1}$ Maureen M. Mamesah \\ ${ }^{2}$ Vonny N. S. Wowor \\ ${ }^{2}$ Krista V. Siagian
${ }^{1}$ Kandidat Skripsi Program Studi Pendidikan Dokter Gigi Fakultas Kedokteran
${ }^{2}$ Program Studi Pendidikan Dokter Gigi Fakultas Kedokteran
Universitas Sam Ratulangi Manado
Email: oyinmamesah@yahoo.com

\begin{abstract}
Teeth become one of the important parts of the body, therefore, one can not be said be healthy as a whole if one's teeth and mouth are in problem. Tooth loss should be handled with the use of dentures. If tooth loss is not replaced soon, it will interfere the mastication, speech function, and aesthetic. However, not all people who have lost their original teeth use dentures. The decision of a person's actions are influenced by perception, such as decision to use the denture or not. Perception about the use of denture is the stimulus in interpretation of individuals regarding the use of denture and the level of knowledge about the importance of the denture. This was a descriptive study with a cross sectional design by using questionnaire. This study population was people in the age group 30-50 years in Tompaso with a total of 2,031 people. Method of sampling was purposive sampling method with a sample size of 64 people. The results indicated that the perception of the public in district Tompaso to the purpose and functions of the use of denture was quite enough with a percentage $54.15 \%$.
\end{abstract}

Keywords: perception, society, denture

\begin{abstract}
Abstrak: Gigi menjadi salah satu bagian tubuh dengan fungsi yang penting, oleh sebab itu seseorang tidak dapat dikatakakan sehat secara utuh bila gigi dan mulutnya bermasalah. Kehilangan gigi seharusnya ditangani dengan pemakaian gigi tiruan karena hilangannya gigi yang tidak segera diganti akan menimbulkan gangguan terhadap fungsi pengunyahan, fungsi bicara maupun estetik. Akan tetapi saat ini tidak semua orang yang telah kehilangan gigi aslinya menggunakan gigi tiruan.Pengambilan keputusan terhadap tindakan seseorang dipengaruhi oleh persepsi, demikian halnya ketika seseorang memutuskan untuk menggunakan atau tidak gigi tiruan. Persepsi tentang pemakaian gigi tiruan ialah proses stimulus yang diinderakan oleh individu mengenai pemakaian gigi tiruan serta tingkat pengetahuan masyarakat mengenai pentingnya pemakaian gigi tiruan. Penelitian ini merupakan suatu penelitian deskriptif dengan pendekatan potong lintang dan menggunakan kuesioner. Populasi penelitian ini ialah masyarakat pada kelompok usia 30-50 tahun di Tompaso yang berjumlah 2.031 orang. Metode pengambilan sampel yaitu Purposive Sampling Method, dengan jumlah sampel 64 orang. Hasil penelitian menunjukan persepsi masyarakat kecamatan Tompaso terhadap tujuan dan fungsi pemakaian gigi tiruan tergolong cukup, dengan persentase $54,15 \%$.
\end{abstract}

Kata kunci: persepsi, masyarakat, gigi tiruan.

Gigi merupakan salah satu bagian tubuh yang memiliki fungsi penting diantaranya berfungsi dalam proses pengunyahan maupun berbicara. Kesehatan gigi dan mulut menjadi bagian penting dari kesehatan secara keseluruhan, dimana 
seseorang akan dikatakan sehat tidak hanya karena tubuhnya yang sehat tetapi juga termasuk didalamnya gigi dan rongga mulut. Jika gigi rusak, tidak teratur susunannya ataupun hilang akan berdampak buruk bagi kesehatan seseorang. ${ }^{1}$

Kehilangan gigi yang kemudian dibiarkan begitu saja dan tidak diganti akan menimbulkan gangguan terhadap beberapa fungsi yakni fungsi pengunyahan, fungsi bicara dan yang tidak kalah pentingnya fungsi estetik. Tidak adanya gigi, baik sebagian ataupun seluruhnya menyebabkan terganggunya fungsi pengunyahan, gangguan dalam berbicara, serta gangguan dalam penampilan seseorang. Semua dampak ini akan sangat berpengaruh pada kenyamanan sehingga dapat menghambat aktivitas. Kehilangan gigi dapat dialami oleh siapa saja. Penyebabnya bisa beragam, bisa karena alasan fisiologis ataupun akibat buruknya status kesehatan gigi terutama karena penyakit periodontal, trauma, karies, dan bisa juga karena kegagalan perawatan sebelumnya atau gangguan pertumbuhan. ${ }^{1}$

Gigi yang telah hilang seharusnya mendapatkan perawatan yaitu dengan pemakaian gigi tiruan, namun pada kenyataannya saat ini tidak semua orang yang telah kehilangan gigi aslinya kemudian memakai gigi tiruan. Berdasarkan prevalensi nasional masalah gigi dan mulut adalah 25,9\%, sebanyak 14 provinsi mempunyai prevalensi masalah gigi dan mulut diatas angka nasional dan Sulawesi Utara termasuk didalamnya. ${ }^{2}$ Sebagian masyarakat justru membiarkan gigi yang telah hilang tidak diganti begitu saja. Menurut hasil Riskesdas tahun 2007, prevalensi kehilangan gigi di Indonesia mencapai 39,1\% sementara pengguna gigi tiruan hanya sekitar 4,5\% dari jumlah populasi penduduk Indonesia. ${ }^{2}$ Angka ini sangat kecil jika dibandingkan dengan jumlah kehilangan gigi.

Pengambilan keputusan terhadap tindakan seseorang antara lain dipengaruhi oleh persepsi demikian halnya ketika seseorang memutuskan untuk menggunakan atau tidak gigi tiruan. Persepsi merupakan sebuah proses stimulus yang diinderakan oleh individu dan kemudian diinterpretasikan, sehingga individu dapat menyadari, mengerti tentang apa yang diinderakan. ${ }^{3}$ Kecilnya prevalensi pengguna gigi tiruan dipengaruhi oleh beberapa faktor, seperti faktor individu yang meliputi ketidaknyamanan pada saat memakai gigi tiruan, mahalnya biaya pembuatan gigi tiruan, lamanya waktu yang dibutuhkan untuk pembuatan gigi tiruan, serta perbedaan persepsi dalam masyarakat tentang pentingnya pemakaian gigi tiruan sebagai pengganti gigi asli yang telah hilang. ${ }^{4,5}$

Adanya latar belakang di atas mendorong penulis untuk melakukan penelitian tentang persepsi masyarakat terhadap pemakaian gigi tiruan. Penulis memilih lokasi kecamatan Tompaso sebagai lokasi penelitian setelah melakukan pengamatan di tempat tersebut, dari jumlah keseluruhan populasi sebanyak 7306 jiwa, banyak yang telah kehilangan gigi aslinya namun sebagian besar memilih tidak memakai gigi tiruan dan membiarkan gigi yang hilang tidak diganti begitu saja.

\section{BAHAN DAN METODE PENELITIAN}

Penelitian ini didesain sebagai suatu penelitian deskriptif dengan metode pendekatan cross-sectional study. Penelitian ini dilaksanakan mulai tanggal 8 Juni-13 Juni 2015 di kecamatan Tompaso kabupaten Minahasa. Sampel pada penelitian ini sebanyak 64 orang yang dipilih sesuai dengan kriteria inklusi. Metode pengambilan sampel yang digunakan yaitu Purposive sampling yaitu metode pengambilan sampel dimana sampel dipilih berdasarkan syarat yang ditentukan sendiri oleh peneliti. Variabel penelitian ini yaitu persepsi masyarakat. Instrumen penelitian yang digunakan pada penelitian ini yaitu kuesioner. Dalam penelitian ini, peneliti memberikan kesempatan kepada responden untuk menjawab sendiri pernyataan yang tersedia dalam kuesioner guna melihat dan memberikan penilaian pada persepsi masyarakat terhadap pemakaian gigi tiruan. 
Untuk memperoleh penilaian terhadap persepsi masyarakat, peryataan dalam kuesioner diukur menggunakan skala Likert. Alternatif jawaban dari kuesioner yang diberikan yaitu sangat setuju (SS) diberi skor 5, setuju (S) diberi skor 4, netral (N) diberi skor 3, tidak setuju (TS) diberi skor 2, sangat tidak setuju (STS) diberi skor 1 .

Jumlah skor tertinggi : 5 × $64=320$

Jumlah skor terendah : 1 x $64=64$

\section{HASIL PENELITIAN}

Penelitian dilaksanakan di kecamatan Tompaso kabupaten Minahasa. Jumlah responden dalam penelitian ini yaitu berjumlah 64 responden. Data Tabel 1 menunjukkan bahwa umur responden yang paling banyak ialah pada kelompok umur 40-50 tahun yakni sebanyak 42 orang $(65,7 \%)$ dan kelompok umur dengan jumlah responden yang lebi kecil yakni 3040 tahun.

Tabel 1. Distribusi frekuensi responden menurut usia

\begin{tabular}{ccc}
\hline Usia & $(\mathrm{n})$ & $(\%)$ \\
\hline $30-40$ & 22 & 34,3 \\
$40-50$ & 42 & 65,7 \\
Total & 64 & 100 \\
\hline
\end{tabular}

Data Tabel 2 menunjukkan bahwa jenis kelamin responden laki-laki berjumlah 21 orang (32,8\%) dan jumlah responden perempuan 47 orang $(67,2 \%)$.

Tabel 2. Distribusi frekuensi responden menurut jenis kelamin

\begin{tabular}{ccc}
\hline $\begin{array}{c}\text { Jenis } \\
\text { kelamin }\end{array}$ & (n) & (\%) \\
\hline Laki-laki & 21 & 32,8 \\
Perempuan & 43 & 67,2 \\
Total & 64 & 100 \\
\hline
\end{tabular}

Tabel 3 menunjukkan bahwa tingkat pendidikan responden yang paling banyak ialah SMA/Sederajat yakni 24 orang (37,5\%) dan yang paling sedikit ialah tidak sekolah yakni 2 orang (3,2\%).

Tabel 3. Distribusi frekuensi responden menurut tingkat pendidikan.

\begin{tabular}{ccc}
\hline Tingkat pendidikan & (n) & $\%$ \\
\hline Tidak sekolah & 2 & 3,2 \\
SD & 10 & 15,6 \\
SMP & 15 & 23,4 \\
SMA/Sederajat & 24 & 37,5 \\
Akademi & 5 & 7,8 \\
Universitas & 8 & 12,5 \\
Total & 64 & 100 \\
\hline
\end{tabular}

\section{BAHASAN}

Usia, jenis kelamin dan juga tingat pendidikan seseorang sangat memengaruhi cara berpikir serta pengambilan keputusan individu tersebut. Dimana usia yang semakin dewasa membuat seseorang akan lebih cepat paham dan kemudian menyadari apa yang menjadi kebutuhan bagi menunjang kesehatannya. Begitupun dalam hal jenis kelamin, kebanyakan perempuan lebih memerhatikan penampilannya dibanding laki-laki. Sementara itu tingkat pendidikan juga sangat memengaruhi cara berpikir yang kemudian dapat membentuk persepsi seseorang.

Persepsi erat kaitannya dengan pendidikan, dimana diharapkan seseorang dengan pendidikan tinggi akan semakin luas pengetahuannya sehingga cara dia membentuk persepi juga diharapkan jauh lebih baik. Selain itu, seseorang dengan pendidikan yang lebih tinggi kebanyakan memiliki keuangan yang lebih baik sehingga dapat lebih memrioritaskan kesehatannya termasuk kesehatan giginya. Persepsi tidak hanya terbentuk dari pengetahuan seseorang tapi juga bisa terbentuk berdasarkan pengalaman yang dialami. 
Mamesah, Wowor, Siagian: Persepsi masayarakat kecamatan..

Tabel 4. Distribusi frekuensi persepsi responden terhadap fungsi pemakaian gigi tiruan

\begin{tabular}{|c|c|c|c|c|c|c|c|}
\hline \multirow[t]{2}{*}{ No } & \multirow[t]{2}{*}{ Tujuan } & \multicolumn{5}{|c|}{ Persepsi } & \multirow[t]{2}{*}{ Skor } \\
\hline & & $\begin{array}{l}\text { STS } \\
(1)\end{array}$ & $\begin{array}{l}\text { TS } \\
(2)\end{array}$ & $\begin{array}{l}\mathrm{N} \\
(3)\end{array}$ & $\begin{array}{c}S \\
(4)\end{array}$ & $\begin{array}{l}\text { SS } \\
(5)\end{array}$ & \\
\hline 1 & $\begin{array}{l}\text { Pemakaian gigi tiruan bertujuan } \\
\text { menggantikan daerah gigi yang hilang }\end{array}$ & 0 & 0 & 0 & 112 & 180 & 292 \\
\hline 2 & $\begin{array}{l}\text { Pemakaian gigi tiruan bertujuan } \\
\text { mengembalikan fungsi pengunyahan }\end{array}$ & 0 & 0 & 24 & 160 & 80 & 264 \\
\hline 3 & $\begin{array}{l}\text { Pemakaian gigi tiruan } \\
\text { mengembalikan fungsi bicara }\end{array}$ & 0 & 20 & 150 & 16 & 0 & 186 \\
\hline 4 & $\begin{array}{lccc}\begin{array}{l}\text { Pemakaian gigi } \\
\text { memperbaiki estetika }\end{array} & \text { tiruan } & \text { bertujuan } \\
\end{array}$ & 0 & 0 & 153 & 52 & 0 & 205 \\
\hline 5 & 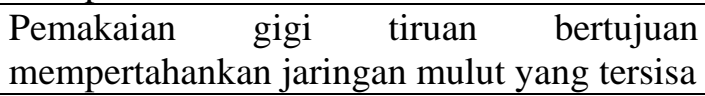 & 0 & 44 & 60 & 88 & 0 & 192 \\
\hline 6 & $\begin{array}{lcr}\begin{array}{l}\text { Pemakaian gigi tiruan } \\
\text { menghindari }\end{array} \text { kemungkinan } & \text { bertujuan } \\
\text { munculnya } \\
\text { berbagai jenis penyakit mulut }\end{array}$ & 2 & 0 & 120 & 72 & 20 & 214 \\
\hline \multirow[t]{3}{*}{7} & $\begin{array}{l}\text { Pemakaian gigi tiruan bertujuan menjawab } \\
\text { kebutuhan masyarakat yang kehilangan gigi }\end{array}$ & 0 & 16 & 3 & 180 & 50 & 249 \\
\hline & & & & & & Total & 1602 \\
\hline & & & & \multicolumn{3}{|c|}{ Skor rata-rata } & 228,85 \\
\hline
\end{tabular}

Tabel 5. Distribusi frekuensi persepsi responden terhadap fungsi pemakaian gigi tiruan

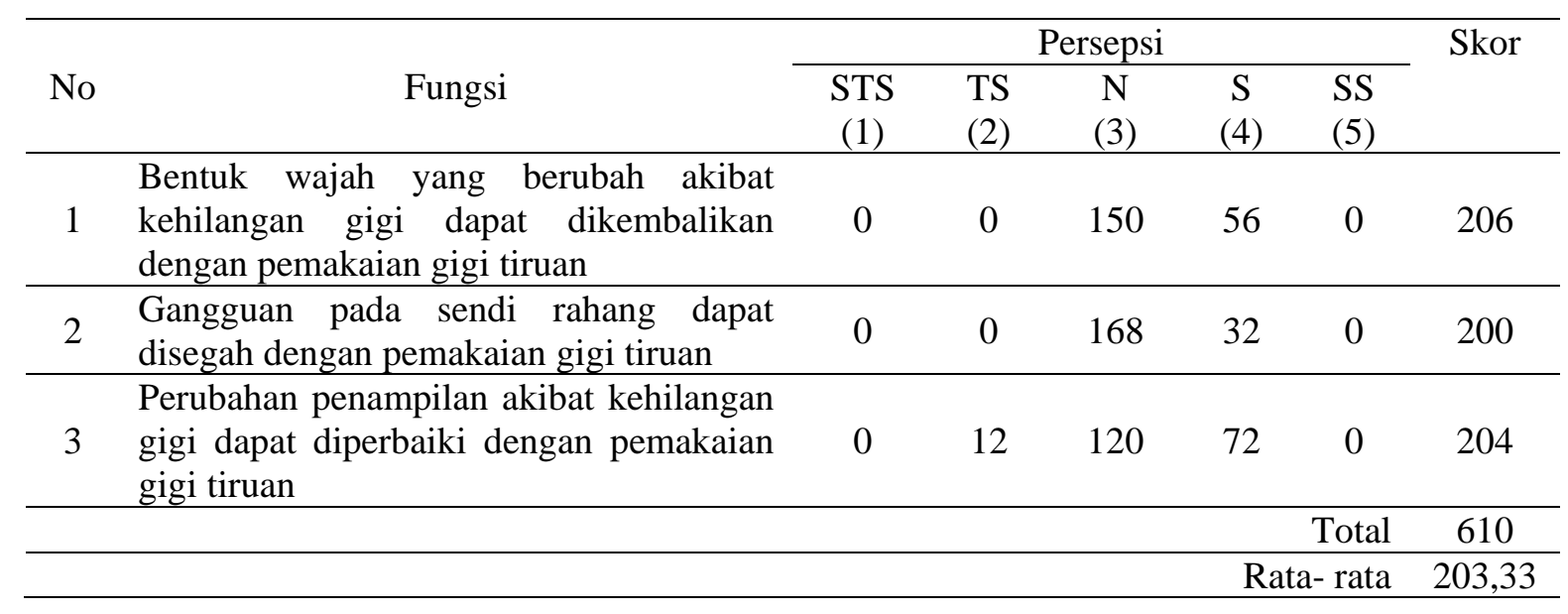

Tabel 6. Distribusi frekuensi persepsi responden terhadap pemakaian gigi tiruan

\begin{tabular}{cccc}
\hline No & Persepsi & $\%$ & Kategori \\
\hline 1 & Tujuan pemakaian gigi tiruan & 56,2 & Cukup \\
2 & Fungsi pemakaian gigi tiruan & 52,1 & Cukup \\
\hline & Rata - rata penilaian & 54,15 & Cukup \\
\hline
\end{tabular}




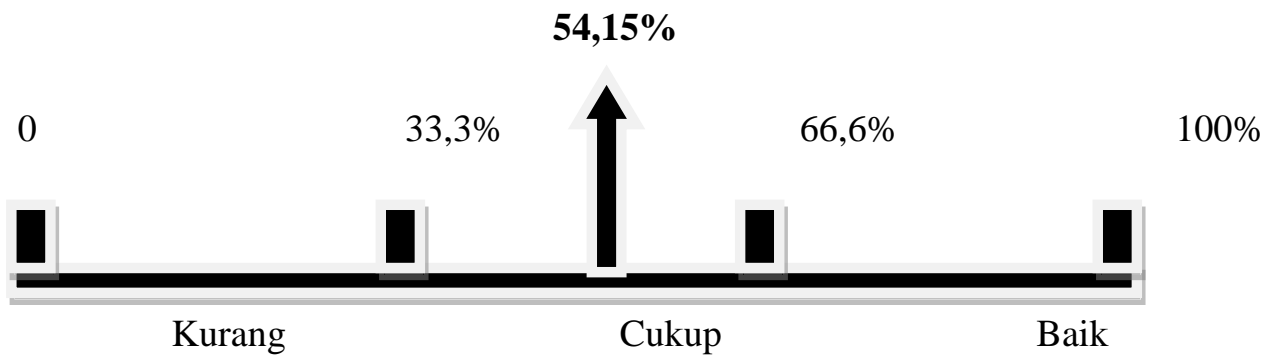

Persepsi masyarakat diperoleh dari berbagai hal yang dapat dilihat, dirasa, didengar, ataupun diraba. Persepsi merupakan faktor predisposisi atau faktor yang mempermudah bagi seseorang untuk mengambil keputusan sehingga dapat terlaksananya suatu perilaku, dalam hal ini perilaku kesehatan terhadap perawatan prostodontia. Perilaku kesehatan menurut Skinner merupakan suatu respon seseorang terhadap objek yang berkaitan dengan sakit, penyakit, serta sistem pelayanan kesehatan, $^{6}$ dimana pelayanan untuk pemakaian gigi tiruan juga termasuk dalam salah satu bentuk pelayanan kesehatan gigi dan mulut.

Dalam penelitian ini, rata - rata perolehan skor persepsi responden terhadap pemakaian gigi tiruan secara keseluruhan termasuk pada kategori cukup (54,15\%). Persepsi ini meliputi persepsi mengenai tujuan dan fungsi pemakaian gigi tiruan. Hasil penelitian ini menunjukkan bahwa hampir semua responden memiliki pengetahuan yang cukup mengenai pemakaian gigi tiruan secara umum. Dimana ketika diberikan pernyataan mengenai tujuan pemakaian gigi tiruan adalah untuk menggantikan gigi yang hilang, rata- rata responden memberikan jawaban sangat setuju ataupun setuju. Begitupun ketika diberikan pernyataan bahwa pemakaian gigi tiruan bertujuan untuk mengembalikan fungsi pengunyahan, memperbaiki estetika, responden kebanyakan memilih jawaban setuju ataupun netral. Sementara untuk pernyataan bahwa pemakaian gigi tiruan bertujuan untuk mengembalikan fungsi bicara dan untuk menghindari kemungkinan munculnya berbagai jenis penyakit, responden memilih jawaban beragam mulai dari sangat setuju,setuju, netral, tidak setuju dan sangat tidak setuju. Pilihan tidak setuju, maupun sangat tidak setuju dari responden bisa dipahami sebagai akibat kurangnya pengetahuan mereka dalam pemakaian gigi tiruan sehingga membentuk persepsi mereka bahwa pemakaian gigi tiruan tidaklah penting.

Pernyataan selanjutnya mengenai fungsi pemakaian gigi tiruan. Sebagian besar responden memilih netral karena mereka belum begitu paham bahwa pemakaian gigi tiruan, dapat mengembalikan bentuk wajah yang berubah menjadi normal yang terjadi akibat kehilangan gigi sementara sebagian kecil responden memilih setuju. Hal ini mengindikasikan bahwa masih sedikit responden yang paham kehilangan gigi dapat merubah bentuk wajah secara keseluruhan yakni, tinggi muka, dan dimensi vertikal serta menyebabkan rahang prognasi. ${ }^{7}$ Individu yang telah kehilangan lebih dari satu gigi terutama gigi posterior bawah profil wajahnya akan berubah, mandibula akan tampak lebih maju. Dalam kehidupan sehari-hari pada individu yang telah kehilangan seluruh gigi terlihat rahang bawah lebih maju dari posisi normal. Dengan memakai gigi tiruan maka perubahan ini akan dapat diperbaiki sehingga hubungan antara rahang atas dan bawah dapat kembali seperti semula.

Gangguan sendi rahang dapat dicegah dengan memakai gigi tiruan merupakan fungsi selanjutnya, namun hanya sedikit responden yang tahu mengenai hal tersebut dan memilih sutuju dengan pernyataan tersebut. Sebagian besar responden masih ragu-ragu dan kurang paham sehinggga 
memilih netral. Kehilangan gigi terutama pada daerah posterior mengakibatkan mekanisme neuromuscular akan membentuk pola pergerakan baru rahang bawah untuk mengompensasi posisi gigi yang baru akibat ketidakserasian dengan gigi lainnya dalam fungsi mulut. Sisa gigi yang ada akan mencoba beradaptasi dengan pola pergerakan baru tersebut, dengan kemungkinan akan menimbulkan ketidakserasian dalam pergerakan. Adanya kontak prematur akan menyebabkan deviasi pergerakan rahang bawah yang akhirnya akan terjadi disfungsi sendi temporomandibular dan spasma otot yang bisa menyebabkan rasa nyeri. ${ }^{8}$ Bagi yang telah kehilangan gigi terutama gigi belakang akan merasakan tidak nyaman atau bahkan sakit pada bagian TMJ terutama ketika mengunyah makanan karena penyebaran tekanan kunyah yang tidak merata. Individu yang mengalami gangguan sendi dan telah memakai gigi tiruan, perlahan gangguan pada TMJ akan hilang sehingga tidak akan lagi merasakan nyeri atau sakit.

Selanjutnya, sebagian besar responden juga masih kurang yakin bahwa perubahan penampilan dapat diperbaiki dengan memakai gigi tiruan sehingga kebanyakan memilih netral, meskipun cukup banyak juga dari responden yang memilih setuju karena mengerti dengan hal ini sementara hanya beberapa responden saja yang memilh tidak setuju. Sebagian responden yang setuju tahu bahwa jika kehilangan gigi maka penampilan mereka akan menjadi tidak menarik sehingga mereka membutuhkan gigi tiruan sebagai gantinya. Hal ini juga berkaitan dengan tujuan pemakaian gigi tiruan yaitu untuk memperbaiki estetik. Seseorang yang mengalami kehilangan gigi namun telah memakai gigi tiruan akan lebih percaya diri untuk berinteraksi dengan orang lain, tidak akan lagi merasa malu atau rendah diri saat berbicara atau tertawa di depan umum.

Secara rata - rata persepsi masyarakat di kecamatan Tompaso terhadap pemakaian gigi tiruan tergolong cukup. Hal ini didukung oleh tingkat pendidikan serta mulai adanya kemauan masyarakat untuk mencari informasi mengenai gigi tiruan baik dari sekolah, dokter gigi, maupun media elektronik hanya saja hal ini masih belum sepenuhnya membuat masyarakat kemudian langsung memilih menggunakan gigi tiruan ketika kehilangan gigi aslinya.

Meski sebagian besar responden paham dan setuju dengan tujuan dan fungsi pemakaian gigi tiruan yang terlihat dari perolehan persentase persepsi pemakaian gigi tiruan yakni $54,15 \%$ tetapi perlu diingat juga bahwa banyak responden masih memilih untuk tidak menggunakan gigi tiruan karena mereka memiliki pertimbangan-pertimbangan tertentu mengapa mereka tidak memakai gigi tiruan salah satunya karena faktor biaya. Tingginya biaya pembuatan gigi tiruan membuat masyarakat menunda atau tidak mau menggunakan gigi tiruan. Berdasarkan hasil wawancara penulis dengan responden dapat dipahami bahwa responden merasa pemakaian gigi tiruan bukanlah kebutuhan pokok yang mendesak untuk segera dipenuhi apalagi jika kehilangan gigi terjadi hanya pada gigi bagian belakang.

Dengan hasil rata-rata 54,15\% meskipun persepsi masyarakat terhadap pemakaian gigi tiruan sudah tergolong cukup dimana rata-rata masyarakat telah cukup mengenal gigi tiruan, namun masih sangat membutuhkan peningkatan dikarenakan persentasenya masih kurang dari $60 \%$. Hal ini tentu saja memerlukan perhatian dan usaha pengenalan kepada masyarakat mengenai seberapa pentingnya pemakaian gigi tiruan itu. Melalui kerja sama dari dokter gigi dan dinas pemerintah terkait seperti puskesmas dapat di laksanakan upaya penyuluhan kepada masyarakat sehingga masyarakat dapat lebih memahami pentingnya pemakaian gigi tiruan.

Selain itu diperlukan juga upaya pengenalan kepada masyarakat mengenai profesi dokter gigi. Hal ini dikarenakan minimnya pengetahuan masyarakat tentang dokter gigi membuat mereka cenderung enggan untuk berkonsultasi dengan dokter gigi dan bahkan tidak memeriksakan kesehatan giginya kepada dokter gigi. 
Dampaknya kemudian terlihat dimana banyak orang yang lebih memilih membuat gigi tiruan bukan pada dokter gigi tapi justru pada tukang pembuat gigi palsu. Ini perlu diperhatikan bahwa akan ada perbedaan yang sangat besar jika gigi tiruan dibuat oleh dokter gigi dan tukan gigi. Bukan hanya dari segi estetis yang akan terlihat perbedaannya tapi juga dari segi kesehatan gigi. Dokter gigi tidak hanya akan memperhatikan letak dan bentuk gigi tiruan yang benar, tapi juga segala dampak kesehatan yang ada sehingga berujung pada kenyamanan. Sementara tukang gigi, mereka justru lebih memerhatikan penampilan gigi tanpa mempertimbangkan kesehatan gigi dan rongga mulut. Sehingga banyak masyarakat yang menggunakan gigi tiruan dari tukang gigi justru mengalami masalah dengan kesehatan mulutnya, dan ketidaknyamanan pada saat memakai gigi tiruan. Oleh sebab itu masyarakat juga perlu memahami bahwa dokter gigi jauh lebih berkompeten dalam mengatasi masalah kesehatan gigi termasuk didalamnya pemakaian gigi tiruan

\section{SIMPULAN}

Persepsi masyarakat kecamatan Tompaso terhadap pemakaian gigi tiruan secara umum masih tergolong cukup, meliputi :

1. Persepsi masyarakat tentang tujuan pemakaian gigi tiruan tergolong cukup.

2. Persepsi masyarakat tentang fungsi pemakaian gigi tiruan tergolong cukup.

3. Persepsi masyarakat kecamatan Tompaso terhadap pemakaian gigi tiruan tergolong cukup.

Dengan hasil tersebut dapat dilihat bahwa rata-rata masyarakat kecamatan Tompaso cukup memahami pentingnya pemakaian gigi tiruan

\section{SARAN}

1. Disarankan kepada pemerintah kecamatan Tompaso melalui dinas kesehatan, agar dapat melakukan berbagai penyuluhan dan sosialisasi guna menambah informasi kepada masyarakat tentang gigi tiruan serta tujuan dan manfaatnya, sehingga pengetahuan masyarakat bertambah dan menjadi lebih baik.

2. Disarankan kepada masyarakat untuk lebih aktif dalam mencari informasi mengenai pemakaian gigi tiruan agar pengetahuan menjadi lebih bertambah, sehingga masyarakat tidak hanya sekedar tahu tapi juga dapat mengaplikasikan hasil tahu dalam bentuk sikap dan tindakan dalam kehidupan sehari-hari sebagai bagian dari peningkatan derajat kesehatan.

3. Diharapkan kepada peneliti lain untuk melakukan penelitian lebih lanjut dengan permasalahan yang sama. Penelitian ini guna mengevaluasi persepsi masyarakat, agar dikemudian hari dapat lebih mengembangkan kesehatan gigi dan mulut terutama dalam bidang prostodontia.

\section{DAFTAR PUSTAKA}

1. The Global Health Observatory (GHO) is WHO's portal providing acces to data and analysis for monitoring the global health situation. [serial online] 2013; [cited 11 April 2015]. Available from: http://www.who.int/gho.2.

2. Riset kesehatan Dasar (RISKESDAS) 2007. Pemetaan Status Kesehatan Gigi dan Mulut di Indonesia. Jakarta, 2007; p. 1-73.

3. Notoadmojo S. Promosi kesehatan dan ilmu perilaku. Jakarta: Rineka cipta;2007

4. Bortoluzzi MC, et al. Tooth loss, chewing ability and quality of life. Contemp Clin Dent. 2012; 3:393-7

5. Chandra H. Persepsi masyarakat terhadap pemakaian gigi tiruan di desa Ujung Rambung kecamatan Pantai Cermin Kabupaten Serdang [Skripsi]. Jakarta: Universitas Indonesia; 2010

6. Dampak Kehilangan Gigi. [internet] 2010. [diakses 2 April 2015] Available from: URL: http ://lib.Universitas Indonesia.ac.id

7. Mar'at S, Kartono LI, editors. Perilaku Manusia: Pengantar Singkat Tentang Psikologi. Bandung: PT Refika Aditama, 2006. 
Mamesah, Wowor, Siagian: Persepsi masayarakat kecamatan..

8. Walianto S. Asimetri dental dan wajah

[serial online]. 2011. [diakses 22

http://unmas-

maret 2015];5(2). Tersedia dari:

library.ac.id/jurnal_unmas/0.pd 